\section{AIDS and The Sunday Times}

SIR - I was astounded by your two-page leading article attacking The Sunday Times for having the temerity to publish a series of articles that run counter to the accepted theory of the causative agent of AIDS. I am a reader of both The Sunday Times and Nature (and a microbiologist), so feel qualified to give a dispassionate view.

In my opinion, it is quite probable that HIV infection is an important factor that leads to AIDS. However, this does not excuse the behaviour of a respected scientific journal in devoting precious space to attacking a leading exponent of a different view. To say that the "public interest requires that The Sunday Times should not follow its perverse line on the causation of AIDS" is outrageous. There are too many examples in the scientific literature of the then-accepted scientific dogma being overturned by a few individuals with the courage and intelligence to question it.

Surely the point of The Sunday Times articles is not to discourage 'safe sex' by teenagers, but to discourage a completely blinkered scientific approach that is 100 per cent certain that there is no other possible explanation for AIDS than HIV. Richard James

University of East Anglia,

Norwich NR4 7TJ, UK

The following letter was submitted to The Sunday Times on 3 June 1993 but was not published.

SIR - The front-page piece about Wellcome ("Fears over the drug giant's funding of Aids research", 30 May 1993) muddles the very clear separation of the pharmaceutical company (Wellcome Foundation Ltd) and the charity (The Wellcome Trust). Even though your report says there is no suggestion that the trust has distorted its funding to benefit the company, it is full of implications that confuse the two, creating unjustified criticism of the trust.

In my research on components of the AIDS virus, I received useful assistance, in the form of experimental material, but no money or research resources from the pharmaceutical company - this research was funded by the Medical Research Council's AIDS-Directed Programme. I have also regularly acted as a referee on research proposals made to the Wellcome Trust, but I have never received any grant from it. Therefore I believe my comments are unbiased. I have personally observed the great emphasis in the trust on distancing itself from the pharmaceutical company.

When AIDS first became a disease of concern in the United States, the pharmaceutical company was in the enviable position of owning the only drug (AZT) known to affect the progress of the disease and already approved for human use. Eight years later, it is now probable that although AZT changes the early development of symptoms, it has no favourable effect on the long-term prognosis. It was always known that it had harmful sideeffects, but its long-term success in treating the disease could not have been assessed until recently.

It is wrong to criticize the trust for supporting research on AIDS. Other medical research agencies in the United States and the United Kingdom have rightly assigned large resources to the study and treatment of this important epidemic. As the largest source of medical research funding in the United Kingdom, the trust has a clear obligation to take part in this effort. Like other similar organizations (including the research councils which dispense government research funds), it invites scientists contemplating large research proposals to discuss them before making a formal application: but such applications are always evaluated by the traditional method of peer review and decided by an expert committee.

Research necessarily deals with uncertainty, and is undertaken because knowledge is lacking. To criticize trust support for Professor Anderson's epidemiological studies of the spread of the disease, or Professor Pinching's AZT trials, because they are alleged to have helped the sales of AZT, defies logic and betrays ignorance about the way medicine advances. If $\mathrm{Mr}$ Martin Walker believes the Wellcome Trust has used its power of patronage "to open doors for the company at the highest level" (in the words of his article), he will have to prove it in the face of strong evidence to the contrary.

\section{David Blow}

Imperial College of Science,

Technology and Medicine,

London SW7 2BZ, UK

The following letter was written to The Sunday Times in September 1993, but was not published.

SIR - I am writing to ask you to consider the manner in which your newspaper is treating the issue of HIV and AIDS.

In response to the 29 August article by Neville Hodgkinson, I wrote to your letters section. I received an acknowledgement and an apology that there was insufficient space to publish. Naturally, you cannot print all the letters you receive, but I was surprised that last Sunday's edition gave equal weight to correspondence supporting and deploring Hodgkinson's article.

I cannot believe that the balance of mail was reflected by the selection of letters you published. Is it your policy to back up your own journalist, regardless of how misleading and irresponsible his article may have been? If so, I would ask you to give serious consideration to the consequences of this action.

All indicators suggest that the incidence of HIV infection in the United Kingdom is relatively low at present, but its high prevalence elsewhere in the world should guard us against complacency. You will be aware of the government money that has already been spent to inform the public on this issue, and that Hodgkinson is undermining this message. Can this really be justified as a public service, or even a legitimate use of press freedom? Scientists and doctors involved with AIDS know just how nonsensical Hodgkinson's articles are, but are powerless to dispel the confusion he has created among those less aware of the facts.

As a personal acquaintance of the original "HIV doesn't cause AIDS" guru (Dr Peter Duesberg), I know all the false premises and bogus arguments only too well. The arguments are a rerun of the tobacco companies' favourite old chestnut "smoking doesn't cause cancer", are equally futile and potentially just as damaging to public health.

Is it your intention to seek advice from more reputable sources and to try to set the record straight in future Sunday Times articles on this important issue?

\section{James C. Neil}

(Member of MRC AIDS Directed Programme Steering Committee),

Department of Veterinary Pathology,

University of Glasgow,

Glasgow G61 1QH, UK

The following letter was submitted to The Sunday Times on 14 December 1993, but was not published.

SIR - Following last Sunday's edition of The Sunday Times (12 December 1993), I feel compelled to write to you about the bizarre stance adopted by your Scientific Correspondent, Neville Hodgkinson, on the subject of HIV and AIDS.

Over the past 15 years I have been involved in several contentious issues which, on occasion, have brought me into conflict with the scientific establishment and members of my own profession. During this time I have always based my case on the scientific data available and, to this end, have organized conferences and edited books so that the data available can be properly evaluated. In addition, I have always invited co-editors who are regarded as pre-eminent in their field.

Many of the contentious issues in these different fields (biological effects of lowlevel lead, ionizing radiation, ozone depletion, global warming) have been resolved through communication, and common ground has been found between campaigners and the established experts.

I am sad to say that none of this applies 
to the extraordinary campaign being conducted by your science correspondent. Not only are his arguments specious but he has singularly failed to address the large volume of evidence that undermines his point of view. By ignoring the scientific method - the scientific procedures laid down to distinguish fact from fantasy - he has not only discredited himself, he has seriously damaged the reputation of your newspaper.

Furthermore, your hostile attitude to John Maddox is both unfair and irresponsible. The reason, I suspect, that certain scientists dislike his approach is because he applies the scientific method with considerable rigour, as Jacques Benveniste found to his cost.

In my dealings with Maddox, I have never found him to be anything other than intellectually honest and courteous, and I think his response to your reporting of the AIDS issue is entirely appropriate. Far from being a triumph for The Sunday Times akin to your thalidomide campaign, I think your perception of the AIDS issue is akin to the Hitler diaries.

\section{R. Russell Jones}

Royal Postgraduate Medical School, Hammersmith Hospital,

Du Cane Road, London W12 ONN, UK

\section{Nuclear Ukraine}

SIR - Your article (Nature 365, 599; 1993) on the US-Ukraine stalemate over nuclear weapons prompts the following remarks. The United States made a mistake in not recognizing Ukraine as a legitimate successor state to the Soviet nuclear arsenal and is still insisting that Ukraine give up its nuclear weapons to Russia. That policy goes back to President George Bush's ill-advised lecture to the Ukrainian parliament advising it not to leave the Soviet Union. John J. Mearsheimer (Foreign Affairs, Summer 1993, p. 50) has suggested that it is not too late to change course and to support a Ukrainian nuclear deterrent against Russia.

Ukraine, the Baltic republics and other former Soviet subject nations are currently targets of Russian neo-imperialist policies. Russia's immediate objectives are aimed at controlling territories necessary for the projection of its naval power. In the Far East, this has meant control of the Kurile Islands. Russia is willing to do without billions of dollars of aid from Japan just to prevent its nuclear submarines from being bottled up in the Sea of Okhotsk. The coastal real estate of the Baltic states is valuable to Russia for the same reason, and Russia has done all it can to put former communists in power there. They succeeded in Lithuania, but opponents of former communists won the elections in Estonia and Latvia. Russia then started a disinformation campaign against Estonia and Latvia, with Boris Yeltsin himself complaining of ". . . a massive violation of human rights. . ." of their Russian minorities and halting the withdrawal of the Red Army to "protect" these colonists from the Soviet era. The New York Times (22 November 1992) subsequently reported that "a week-long investigation into Mr Yeltsin's allegations in Estonia and Latvia finds little evidence of human-rights abuses, at least as commonly understood".

The pressure continues, however, on the diplomatic front and has more recently taken the form of opposing the admission of the Baltic states to the European Union and of former Warsaw Pact members to NATO. The Cold War may be over, but Russian generals are all former Soviet generals, they still have a huge army, their military/industrial complex is still a drag on the economy and is yet to be dismantled, a sanitized $\mathrm{KGB}$ is still in business under a new name, and nobody has yet been punished. Can anybody be surprised?

Arno Arrak

5 Chatham Place,

Dix Hills, New York 11746, USA

\section{Mercury exposure}

SIR - We would like to add to the accounts $^{1.2}$ of mercury poisoning that have recently appeared. We discovered an elevated mercury concentration in the urine of a 2-year-old girl in a refugee camp in Germany. Subsequent investigations revealed that other family members and other inhabitants of the camp had high concentrations of mercury in the urine.

The camp is next to a coal-fired power plant and is inhabited mostly by refugees from former Yugoslavia and from Romania. Some families, including those with high mercury levels, have lived there for several years, and many of the younger children were born in Germany. Mercury concentrations were not always elevated. There were families with high levels and apparently unexposed families. Women tended to have a much higher concentrations (see figure).

After a long search for the source of this contamination, a physician from Kosovo helping us as an interpreter discovered that all the exposed families used a cosmetic bleaching ointment containing rose oil and a mercury salt; the ointment had to be buried for a year for proper seasoning. It was sold by a Turkish vendor. In two samples we found concentrations between 708 and $17,200 \mu \mathrm{g} \mathrm{Hg}$ per g ointment.

We went into two camps and investigated all children in whom we had detected elevated mercury values. Their age and urinary and blood mercury concentrations at the time of clinical investigation are shown in the figure. None had any

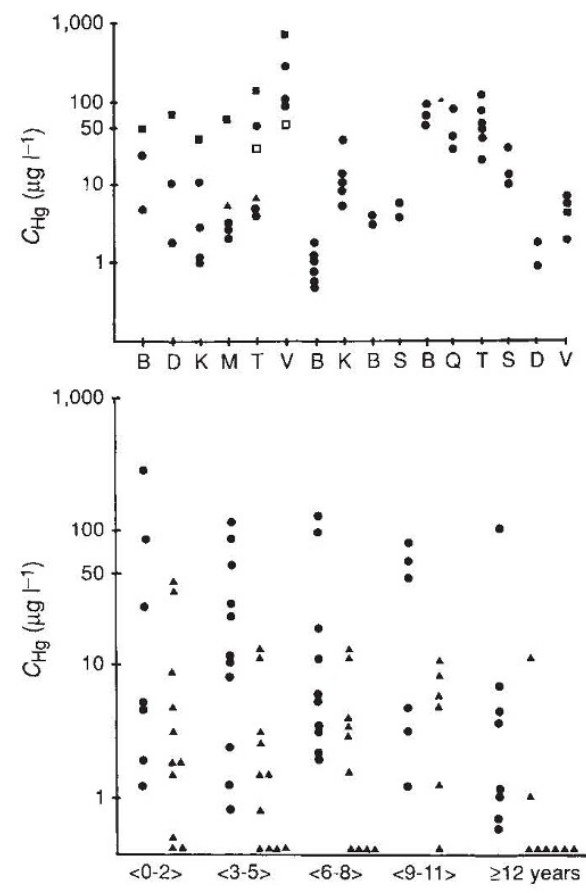

Top panel, urinary mercury excretion by individual members of 16 different families. (The letters represent the initial letter of the family name.) $\mathbf{\square}$, Mothers; $\boldsymbol{\Delta}$, fathers; $\bullet$, children; $\square$ female relatives. Lower panel, mercury concentration in urine $(\bullet)$ and blood $(\mathbf{A})$ in children at the time of clinical investigation. In some cases it was not possible to collect both samples.

dermatological, neurological or behavioural signs of acrodynia.

One woman with a $\mathrm{Hg}$ concentration of $150 \mu \mathrm{g} \mathrm{l}^{-1}$ in urine and $29.9 \mu \mathrm{g} \mathrm{l}^{-1}$ in blood had given birth to a normal baby $(50 \mathrm{~cm}$, $3,060 \mathrm{~g}, 34 \mathrm{~cm}$ head circumference). The placenta contained $120 \mu \mathrm{g} \mathrm{Hg} \mathrm{kg}$. The mercury concentration in the umbilical blood was $8.8 \mathrm{\mu g} \mathrm{l}^{-1}$. This boy was four weeks old when we saw him. He was clinically and neurodevelopmentally normal.

There are few data on the incidence of acrodynia at various mercury concentrations, some dating back 40 years ${ }^{3}$. In our patients, much higher mercury concentrations were measured and tolerated without the manifestation of clinical signs in several cases described in the literature. There may be a wide range of individual, possibly also ethnically conditioned, variation of susceptibility in children to low, chronic mercury exposure.

\section{Otto}

C. Ahlemeyer

Hedwig Tasche

K. E. von Mühlendahl

Akademie für Kinderheilkunde

und Jugendmedizin,

Iburger Str. 200 ,

49082 Osnabrück,

Germany

1. Wendroff A. P Nature 347, 623 (1990)

2. Mills, A. Nature 346, 615 (1990)

3. Warkany, \&J. Hubbard, D. M. Lancet 1, 829-830 (1948). 